\title{
Ciaran Carson and the Theory of Relativity
}

Julia C. Obert

\section{(C) OpenEdition}

\section{Journals}

\section{Electronic version}

URL: http://journals.openedition.org/etudesirlandaises/5152

DOI: 10.4000/etudesirlandaises.5152

ISSN: 2259-8863

\section{Publisher}

Presses universitaires de Rennes

\section{Printed version}

Date of publication: 29 June 2017

Number of pages: $123-137$

ISBN: 978-2-7535-5495-5

ISSN: 0183-973X

\section{Electronic reference}

Julia C. Obert, «Ciaran Carson and the Theory of Relativity », Études irlandaises [Online], 42-1| 2017, Online since 29 June 2019, connection on 07 September 2019. URL : http://journals.openedition.org/ etudesirlandaises/5152; DOI : 10.4000/etudesirlandaises.5152 


\title{
Ciaran Carson and the Theory of Relativity
}

\author{
Julia C. OBert \\ University of Wyoming
}

\begin{abstract}
Ciaran Carson's poetry collection Until Before After (2010), written while Carson's wife Deirdre was seriously ill, turns and returns to sickness and the spectre of death. However, it finds some relief from anxiety and grief in the interweaving of poetry and theoretical physics specifically, in Einstein's theory of general relativity. Both space and time, the volume contends, are observer-dependent; we do not exist on a linear continuum, and so life and after-life are actually simultaneous. As one contemplates being-towards-death, Carson indicates, these insights can be surprisingly therapeutic. Additionally, traditional music provides the basis for a new, non-Euclidean worldview in Until Before After. As Carson's work on traditional music suggests, the genre can evade conventional measures of time. For instance, sometimes "a good musician can produce a pulse against the ostensible rhythm of the tune", a technique that Carson calls "double entendre - like hearing two beats at once". Until Before After borrows such double entendres from traditional music, allowing the poetry to offer a kinetic, relativistic, nonlinear means of apprehending space and time.
\end{abstract}

Keywords: Ciaran Carson, Until Before After, space, time, physics.

\section{Résumé}

Dans recueil Until Before After (2010), écrit alors que sa femme Deirdre était atteinte d'une maladie grave, Ciaran Carson revient sans cesse sur la maladie et le spectre de la mort. Il trouve cependant un certain répit à l'angoisse et à la douleur en mêlant poésie et science physique - en particulier dans la théorie de la relativité d'Einstein. Le recueil dans son ensemble suggère que l'espace et le temps dépendent de qui les observe. Nous n'existons pas dans un continuum linéaire, et par conséquent la vie et le temps qui lui succède sont en réalité simultanés. Carson montre que ces intuitions peuvent être puissamment thérapeutiques au moment où l'on contemple son être-pour-la-mort. En outre, la musique traditionnelle offre le socle d'une nouvelle vision du monde non-euclidienne dans Until Before After, car ce genre peut s'affranchir des modalités conventionnelles de mesure du temps. Ainsi, parfois " un bon musicien peut faire surgir une pulsation qui va à l'encontre du rythme immédiatement perceptible de la mélodie ", technique que Carson qualifie de "double entendre comme si l'on entendait deux pulsations en même temps. "Until Before After emprunte ce double entendre à la musique traditionnelle, et permet à la poésie de proposer un mode d'appréhension du temps kinétique, relativiste et non-linéaire.

Mots clés : Ciaran Carson, Until Before After, espace, temps, physique. 
Ciaran Carson's poetry has long argued for the importance of perspective: in his writing, seeming absolutes are often " $\mathrm{t}[\mathrm{old}] \ldots$ slant $\mathrm{t}^{1}$, and how one sees depends largely on where one stands. Carson frequently raises the concept of subjective situatedness in relation to the conflict in Northern Ireland, suggesting that sectarianism is bred rather than inborn and offering alternatives to partisanship by providing "shifts in position and perspective" in his work ${ }^{2}$. In his most recent original collection, Until Before After (2010), though, Carson's preoccupation with perspectivalism becomes even more pronounced. Written chiefly while his wife Deirdre was seriously ill (happily, she has since recovered), the volume turns and returns to sickness and the spectre of death ${ }^{3}$. However, it finds some relief from anxiety and grief in the interweaving of poetry and theoretical physics - specifically, in Einstein's theory of general relativity.

Carson has been interested for many years in such theories. In a 2000 interview with John Brown, he explains:

Language may be dodgy but we need it to talk with. Life is dodgy. Matter itself, things, if we are to believe the quantum physicists, is very dodgy indeed. The funny thing is that I think the essences of things can cross space and time, maybe because of that very dodginess. As if the matter of the poems were in the ether, swirling around invisibly for the last century or $\mathrm{so}^{4}$.

Although here Carson is discussing his poetic process, in Until Before After, he brings this "dodginess" to bear on life and death themselves. Both space and time, the volume contends, are observer-dependent; we do not exist on a neat linear continuum, and so life and after-life are actually simultaneous. As one contemplates being-towards-death, Carson indicates, these insights can be surprisingly therapeutic. In fact, Einstein himself, after his friend Michele Besso's death, wrote to Besso's sister and son that departing the world as we know it means little in the face of physics: "People like us, who believe in physics, know that the distinction between past, present, and future is only a stubbornly persistent illusion" ${ }^{5}$. With his wife in hospital, Carson takes up much the same argument, taking comfort in this meeting of the sacred and the scientific. Ultimately, then, Until Before

1. Ciaran Carson, Opera Et Cetera, Newcastle upon Tyne, Bloodaxe, 1996, p. 19.

2. Jonathan Stainer, "The possibility of non-sectarian futures: emerging disruptive identities of place in the Belfast of Ciaran Carson's The Star Factory", Environment and Planning D: Society and Space 23 (2005), p. 390.

3. Although the text never names Deirdre directly, Carson has revealed at readings that these poems take up the subject of his wife's illness (see Naomi Marklew, "Remembering and Dismembering: Ciaran Carson's Elegies for Belfast”, Irish University Review 45.2, 2015, p. 368).

4. Ciaran Carson, Interview with John Brown, In the Chair: Interviews with Poets from the North of Ireland, Ed. John Brown, Cliffs of Moher, Salmon, 2002, p. 151.

5. Quoted in Freeman J. Dyson, Disturbing the Universe, New York, Basic Books, 1979, p. 193. 
After ends up theorizing away its titular concepts - or at least asserting that these concepts are subjective rather than given - in order to subvert death's seeming finality.

\section{Seeing and believing}

In order to lay the groundwork for his engagement with space-time, Carson peppers the first half of Until Before After with a trope familiar to his long-time readers: that of refracted perspective. As I have argued elsewhere, Carson's poetry frequently severs seeing from believing ${ }^{6}$. His collections suggest that there is no absolute knowing, only apprehending an object or event from a situated perspective - and even that apprehension can shift with the passage of time. This is why Carson's "Revised Version" quips that "[t]he city is a map of the city"; no cartographer can keep pace with Belfast's builds and demolitions, no snapshot can capture the turbulent energies of its loneys and by-ways. As Alan Gillis puts it, it is impossible to "see what's before your eyes" in Carson's work because the poetry "turbinates with the relativity and contradictions of multi-perspectivalism" ${ }^{8 "}$. Until Before After is no exception to this rule; the volume describes scenes from various points of view, revealing each standpoint as partial and provisional and calling fixed perspectives into question.

Early in the collection's "Before" section, perspective begins to proliferate kaleidoscopically. For example, "An airman" and "From below," which are juxtaposed in the volume, offer contrasting views of a bank of clouds. The airman, of course, takes in the scene from above the fray: he "sees through gaps/in the cloud-/cover the movements/of armies/yet without radio/cannot communicate". In contrast, the ground-level viewer sees "From below", and s/he apprehends "a great cloud/roped like/a heavy cable/being slowly paid/by its own weight/before settling into/gross coils ${ }^{10}$ ". We are not told whether these scenes are simultaneous - and in a sense, this temporal ambiguity proves Carson's point. (That said, two pages later, the poem "Which cloud" suggests a potential confluence of events: here the speaker lies "on my back/on the green grass," then suddenly sees "clouds/ of explosion boom[ing]/from the horizon ${ }^{11}$ ".) The cloud-watcher in "From Below" is focused on the coils of cabled vapor overhead, and if the advancing

6. Julia C. Obert, Postcolonial Overtures: The Politics of Sound in Contemporary Northern Irish Poetry, Syracuse, Syracuse UP, 2015, p. 24.

7. Ciaran Carson, "Revised Version”, Belfast Confetti, Winston-Salem, N.C., Wake Forest UP, 1989, p. 66.

8. Allan Gillis, "Ciaran Carson and History", The Cities of Belfast, ed. Nicholas Allen and Aaron Kelly, Portland, Four Courts Press, 2003, p.183.

9. Ciaran Carson, “An airman”, Until Before After, Winston-Salem, N.C., Wake Forest UP, 2010, lines 1-6.

10. "From below", ibid., lines 1-7.

11. "Which cloud", ibid., lines 2-3, 8-10. 
troops are indeed nearby, they are beyond his/her line of sight. In other words, this narrator's perspective is limited, and s/he cannot know what surpasses his/ her visual field. The airman's bird's-eye view, on the other hand, affords him a miniaturizing perspective on the events below. He can see the troops mobilizing, advancing a coordinated attack. If we imagine his poem's future, though - which Carson invites us to do, telling us that the airman "sees what lies before/his loved

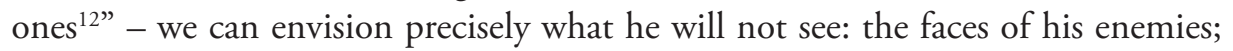
the battlefield carnage. Carson therefore implies that every perspective is limited, and that every view of the world is relative. No onlooker, not even a high-flying top-down spectator, can be omniscient ${ }^{13}$.

Likewise, the poem "The lightning" offers multiple perspectives on the same scene, reiterating the idea that sight is subjective. The poem's narrator sees lightning strike, and describes how to his/her eye, its illumination seems "white like/a flash from/a looking glass." However, a second viewer sees the same flash as "rose-/ coloured and lilac," a kind of electrostatic rainbow ${ }^{14}$. The poem does not resolve the contradiction, nor does it try to explain why one person's white light is another's prismatic array - it simply offers double vision as a condition of intersubjectivity $^{15}$. This is not to imply that matter is static and that our sensory faculties are deceptively variable; in fact, as Doreen Massey explains, "[i]n modern physics, ... the identity of things is constituted through interactions ... [between t] he observer ... [and] the observed world ${ }^{16 "}$. By granting both the narrator and the other's descriptions of the lightning equal weight, Carson reiterates Massey's point: it is not simply that sight is subjective (that either the narrator or his colleague is 'correct'), it is that space itself is observer-dependent ${ }^{17}$.

12. “An airman", ibid., lines 11-12.

13. The intertextualities of these two poems also offer a refracted narrative perspective: "An airman" recalls Yeats' famous WWI poem, "An Irish Airman Foresees His Death", while "From below” is taken nearly verbatim from an 1871 entry in Gerard Manley Hopkins' journal. "The lightning”, too, is borrowed in part from Hopkins' journal, with the initial viewer being Hopkins himself and the second Victor Lentaigne, a fellow Jesuit.

14. Ciaran Carson, "The lightning", Until Before After, op. cit., lines 1-3, 5-6.

15. Our idiosyncratic points of view, of course, don't necessarily mean mutual misunderstanding. Carson has said in interview that storytelling is an imaginative effort to "see the world through another's eyes", and in "The lightning" the 'I's' "eye zigzag[s]" with precisely this sort of effort (see "For All I Know: Ciaran Carson in Conversation with Elmer Kennedy-Andrews", Ciaran Carson: Critical Essays, ed. Elmer Kennedy-Andrews, Dublin, Four Courts, 2009, p. 24, 13).

16. Doreen Massey, "Politics and Space/Time", New Left Review I/196, 1992, p. 76.

17. One of the most compelling indications of "the observer effect" in quantum physics is the so-called double-slit experiment. In this experiment, a series of photons are fired at a plate with two slits. If no one watches the experiment, the photon acts like a wave, and passes through both slits at the same time. However, if an observer witnesses the experiment, each photon travels through only one of the slits. The experiment therefore implies that a photon does not have a location in space-time until it is observed, and that all matter is inherently probabilistic. (For a good explanation of this experiment, see Vesselin Petkov's "Physical Laws and Worldlines in Minkowski Spacetime", in Minkowski Spacetime: A Hundred Years Later.) 
Neal Alexander's 2010 book-length study of Carson's writing, written just before the publication of Until Before After, describes Carson's poetry as producing "an effect akin to that of parallax, whereby shifts in perspective lay bare the processes through which [...] place is constructed and deconstructed ${ }^{18}$ ". Carson's prose works also feature such disorienting shifts; in his 2001 novel Shamrock Tea, for instance, Jan van Eyck's painting The Arnolfini Portrait serves as a wormhole of sorts, a portal that transports Carson's young narrator to other times and places. Shamrock Tea therefore thematizes point of view - its narrator is at one moment an Irish Catholic schoolboy, and at the next a librarian at an asylum in Ghent in order to "call the codes by which our own version of 'reality' is constructed into question ${ }^{19}$ ". Such questions are foregrounded even more prominently in Carson's most recent collection, with poems like "The lightning" revealing space as a shared (and sometimes unshared) vision rather than a fixed field.

\section{Life in four dimensions}

Beyond asserting matter's "dodginess ${ }^{20}$ ", Until Before After takes Carson's quantum insights a step further. In this volume, Carson insists that we consider life in four dimensions; by constantly conflating, even confusing, spatial references with temporal terms, his poems think in space-time rather than in Euclidean geometry. This shift relies on Einstein's theory of general relativity, a theory that drew on Hermann Minkowski's earlier research to frame space and time as parts of a single four-dimensional fabric (versus treating time as a constant distinct from space's three dimensions). Relativity indicates that temporal simultaneity is actually in the eye (or ear) of the beholder: it depends on one's relative rate of motion and on the strength of one's gravitational field ${ }^{21}$. As physicist, Brian Greene explains, this means that there is no "universal now": "Clocks that are in relative motion or that are subject to different gravitational fields tick off time at different rates; the more these factors come into play, the further out of synchronization the clocks will fall. Individuals carrying such clocks will therefore not agree on what happens when ... [and so] what constitutes a moment in time is completely subjective ${ }^{22 "}$.

Once we involve motion and velocity in our understandings of space, linear concepts of reality are upended, and notions of past, present, and future are revea-

18. Neal Alexander, Ciaran Carson: Space, Place, Writing, Liverpool, Liverpool UP, 2010, p. 3.

19. Ibid., p. 170.

20. Ciaran Carson, Interview with John Brown, op. cit., p. 151.

21. Hans Reichenbach, Defending Einstein: Hans Reichenbach's Writings on Space, Time, and Motion, Cambridge, Cambridge UP, 2006, p. 102.

22. Brian Greene, "The Time We Thought We Knew," New York Times, 1 January 2004, [http://www.nytimes. com/2004/01/01/opinion/the-time-we-thought-we-knew. html?_r=0]. 
led to be fluid. Put otherwise, "[r]elativity strongly suggests that the whole history of the world is a timeless unity; present, past, and future have no meaning apart from human subjectivity ${ }^{23 "}$. It is not just sight, then, that is perspectival - our sense of both where we are and when we are depends on our individual situatedness. For Carson, who is facing his wife's illness and contemplating mortality, these insights are a tonic of sorts. If we "shatter [...] our comfortable sense that the past is gone, the future is yet to be and the present is what truly exists ${ }^{24 "}$, we must confront the vertiginous possibility that life and the afterlife always already coexist.

The first gesture towards Carson's interest in space-time in Until Before After is the title of the collection. Carson organizes the volume around its three titular prepositions, with each term heading its own section of 51 poems. Additionally, every poem in the collection at some point incorporates the preposition under which it is filed. The concepts "until", "before", and "after" therefore take on a driving importance in the book. However, these words are all slippery, and their meanings ambiguous. "Until" is a term that usually measures time (often synonymous with something like "up to..."), but without a resolving noun, its meaning is indeterminate. This leaves the word as itself an in-between space - a kind of linguistic bridge to nowhere. Moreover, when Carson deploys "until" in particular syntactical contexts, the term sometimes takes on both spatial and temporal valences. For instance, in the poem "Overhead", the falcons circling overhead eye the ground "until/when or where/they see then/seize their prey" ${ }^{25}$ ". These lines are intentionally indefinite: we cannot know whether the falcons are waiting for the right place, the right moment, or both, to swoop down and attack.

Similarly, the terms "before" and "after" are equally temporal and spatial, and Carson often takes advantage of this flexibility to conflate distance and duration. "Before" is sometimes doubly confusing, as it can connote events in both time and space, as well as in both the past and the future. Indeed, in "Here lies", the line "the road before" seems to indicate a space ("the road") yet to come (here "before" perhaps means "ahead"). However, two lines later, the word pivots, attached to the turn of phrase "all/who went before;" now "before" appears to point towards a time since lapsed ${ }^{26}$. In the light of "before's" second usage, the reader is tempted to return to the first, wondering whether it was indeed a gesture towards the future or whether the poem ought to remain consistently in the past tense. This recursiveness also means that the act of reading the poem is not necessarily

23. Lee Smolin, Time Reborn: From the Crisis in Physics to the Future of the Universe, New York, Mariner Books, 2013, p. 2.

24. Brian Greene, op. cit.

25. Ciaran Carson, "Overhead", op. cit., lines 7-10.

26. Ciaran Carson, "Here lies", op. cit., lines 1-3. 
linear; its own past-ness and futurity are relative. Carson's use of the word "after" is often similarly ambiguous; in "Asleep", when the poet-speaker walks through "ward after ward ${ }^{27 "}$, the gesture is both spatial and temporal, and while in many places, the word clearly points to a past event ("after gazing/at the cloud/.../you watched/the sunflower ${ }^{28}$ "), "For all" pronounces that "after/is not yet ${ }^{29}$ ". This linguistic confusion implies that, for Carson, time and space are part of an interwoven fabric, and it prompts the reader to consider the plasticity of both matter and temporality - the poet's sense that "the essences of things can cross space and time $^{30 "}$.

Carson's conflation of time and space operates thematically as well as syntactically in the collection. In the poem "If presently", for example, the march of time can be gauged geographically: when the city is subject to the movements of the familiar pedestrian, "the hour is/not of the clock/but measured/by.../distances." (That said, these "distances" are also temporal, as they are later described as "epochs of before/fattening in the now ${ }^{31}$ ".) Conversely, "I looked through" depicts the church bells that Carson and his wife can hear from her hospital room as measuring "time after time" as they "boom ... out/over the city ${ }^{32}$ ", but the sound of time passing, here, also locates the hospital in space. Indeed, this recurring temporal-auditory cue, which echoes through the yard of the nearby "old jail ${ }^{33}$ ", helps us to locate the hospital on Belfast's Lower Crumlin Road (it is likely the Mater Infirmorum). Put otherwise, while "If presently" argues that one can gauge the time by the distance one has travelled through the city, "I looked through" suggests that one can also gauge the length and breadth of the city's spaces by the chiming bell, a marker of time.

Once Carson has thus established his desire to render life in four dimensions, he begins to thematize the malleability of time. He follows Bergson in counterposing clock time to lived time or durée - the notion that we often do not experience time as consistent or linear. In this volume, time's relativity is shored up by the monotony of Deirdre's hospital visits; in the light of illness and boredom, the hours pass so slowly that her stays seem almost interminable. In fact, the Wake Forest UP edition of the collection sets the stage for this theme on its cover page by juxtaposing the Rorschach blot of an X-ray - the "shadow" that, "They said" tells us, must be surgically excised ${ }^{34}-$ with the image of a wristwatch. For ins-

\footnotetext{
27. Ciaran Carson, "Asleep", op. cit., line 9.

28. Ciaran Carson, "All day long", op. cit., lines 1-2, 9-10.

29. Ciaran Carson, "For all", op. cit., lines 2-3.

30. Ciaran Carson, Interview with John Brown, op. cit., p. 151.

31. Ciaran Carson, "If presently", op. cit., lines 8-12, 13-14.

32. Ciaran Carson, "I looked through", op. cit., lines 10-12.

33. Ciaran Carson, "From a window ledge", op. cit., line 3.

34. Ciaran Carson, "They said", op. cit., line 1.
} 
tance, in the side-by-side poems "Figure" and "All day long", time seems to slow to a crawl. The former follows the measured plod, "figure/after figure", of "the minute hand/the hour hand" of a clock, and this plod is mirrored by the poem's own deliberate pace, its dwelling throughout on a single image ("the bow the link/ the swivel/the bolt-ring/the escapement ${ }^{35}$ "). "All day long" similarly describes the patient staring out her room's window, watching a cloud that appears not to have "moved/since yesterday ${ }^{36 "}$. In other words, given the tedium of her hospitalization, time seems to hardly advance at all: it is "measured/footfall by footfall/drip by drip ${ }^{37 "}$. Metrically, too, the poems convey a sense of deceleration. Their short lines are methodical, even sluggish, piling monosyllable upon monosyllable ("that had not", "what had been") and stressed beat upon stressed beat ${ }^{38}$. Time creeps along for us as we read, just as it does for Deirdre as she awaits surgery.

Likewise, the volume's 'trauma poems' point to lived time as looping or recursive rather than linear. In trauma, one is repeatedly re-possessed by the traumatic event; it revisits the mind again and again, forcefully and against one's will. Therefore, as Cathy Caruth describes it, "the impact of [trauma] ... lies precisely in its belatedness, in its refusal to be simply located, in its insistent appearance outside the boundaries of any single place or time ${ }^{39}$ ". Carson's poetry has often engaged notions of trauma, although typically this trauma has been that of the Troubles the insecurity of living in a conflict zone. Many critics have commented on this aspect of his writing: Alex Houen, for example, has identified Carson's obsessively recurring images as "exploded tropes", reflections of the "dangerous contingencies of the political situation [in the North] 40 ", while Rand Brandes's "The Dismembering Muse" points to the mutilated limbs in Carson's poetry as obvious indices of the trauma sustained both by individual Northern Irish bodies and by the body politic ${ }^{41}$.

In Until Before After, however, trauma becomes more personal, more intimate. While the poet-speaker is still facing the initial shock of his wife's illness in all its immediacy (the final poem in the collection thematizes their return home from hospital, so we are not yet presented with the episode's aftermath), he anticipates its cyclical return by linking this traumatic event to past hauntings. Several of the poems in the collection are elegies for an unnamed man (perhaps the poet's

35. Ciaran Carson, "Figure", op. cit., lines 1-3, 4-7.

36. Ciaran Carson, "All day long”, op. cit., lines 7-8.

37. Ciaran Carson, "In your absence", op. cit., lines 7-9.

38. Ciaran Carson, "All day long", op. cit., lines 3, 5.

39. Cathy Caruth, ed., Explorations in Memory, Baltimore, The Johns Hopkins UP, 1995, p. 9.

40. Alex Houen, Terrorism and Modern Literature: From Joseph Conrad to Ciaran Carson, Oxford, Oxford UP, 2002, p. 273.

41. Rand Brandes, “The Dismembering Muse: Seamus Heaney, Ciaran Carson, and Kenneth Burke’s 'Four Master Tropes", Bucknell Review: A Scholarly Journal of Letters, Arts, and Sciences 38.1, 1994, p. 177-94. 
father, William Carson/Liam McCarráin), and they describe how the past often re-presents itself very palpably in the present - in other words, how trauma frustrates time's seeming linearity. In "Did not know", memories of the dead return unbidden when the poet-speaker gets a whiff of a familiar aftershave; things that "were until/now forgotten" are vividly re-experienced in the throes of this olfactory cue ${ }^{42}$. Elsewhere, Carson frankly renders the operations of such hauntings by saying, "[r]epeatedly/what was gone/comes back" ${ }^{43}$ ". Relatedly, the poem "Away in" returns the elegized subject briefly to life, depicting him towards the end of his days. In age, his mind takes him "back in time/if not in place", and although it is unclear whether these wormholes of memory lead to moments of pleasure or of pain, Carson tells us that "over/and over/he would return/to that nameless town/though he had long/abandoned it ${ }^{44}$ ". Clearly, then, time in this collection is firmly perspectival rather than universal or absolute.

Some of the poems in Until Before After are, moreover, portals to previous Carson volumes, as they make past themes present. The collection's elegies transport the long-time Carson reader, for example, back to 1989's Belfast Confetti, particularly to "Bed-Time Story" and "Ambition", Carson's earlier odes to his father. In fact, "Ambition", a poem that recounts a father-son hike up Black Mountain, actually sets the stage for Carson's current preoccupation with repetition and recurrence. The poem describes "trauma time" - in this case, William Carson's seemingly involuntary recollections of his seven-week internment while under suspicion of Republican paramilitary involvement - as "a road,/ ... fraught with ramps and dog-legs, switchbacks and spaghetti; here and there,/ The dual carriageway becomes a one-track backward mind ${ }^{45}$ ". Until Before After is rife with such "dog-legs", the zig-zag "switchbacks" of illness and death, as well as with feedback loops that allow Carson's earlier collections to echo throughout his contemporary work.

There are also a number of poems in the volume - particularly in its final third - that explicitly collapse ideas of past, present, and future in order to think more flexibly about being-towards-death. If "before" and "after" are relative terms, then perhaps somewhere, somehow, from some perspective, at some velocity, our dead are still with us. Colin Graham's article about the collection, "strange architecture': Ciaran Carson's Until Before After", argues for a numerological reading of the book (three sections, 51 poems in each section, linked in groups of three, with two five-couplet poems followed by one seven-couplet poem), suggesting that this is a poetry on the verge of divine revelation. Graham concludes, however, that

\footnotetext{
42. Ciaran Carson, "Did not know", op. cit., lines 9-10.

43. Ciaran Carson, "Repeatedly", op. cit., lines 1-2.

44. Ciaran Carson, "Away in”, op. cit., lines 5-6, 9-14.

45. Ciaran Carson, “Ambition”, Belfast Confetti, Winston-Salem, N.C., Wake Forest UP, 1989, lines 13-15.
} 
"where numerology asserts significance and divine pattern, as Augustine believes, Until Before After is a secular book wishing for evidence of the hereafter, putting together the strands and words of a life at a possible moment before death, and straining to see and hear what lies after death ${ }^{46}$ ". I agree with Graham that this collection is a kind of meeting-place of the sacred and the secular, but I think we must extend his analysis: Carson actually deconstructs notions of "before death" and "after death", borrowing from theoretical physics to find the "hereafter" alongside the "here" in the face of his wife's illness.

The poem "What is" offers one such muddying of past and present. "What is/ aftermath", it wonders, "if not swathe/upon swathe/of wave before/wave-break ${ }^{47 "}$ ? In other words, the motion of tides - perpetual, cyclical, and a function of gravitational forces - is a kind of loop in which "before" is also "after"; the two cannot be neatly disentangled. Carson then goes on to conflate "the world to come" with the world "where/we abide" and to juxtapose that which is "nearest in time" with the "nearest timeless ${ }^{48}$ ". These poems set the stage for the ghostly presences that creep into Carson's lines late in the collection - hauntings that subvert the idea of mortality as we know it. For example, "Asleep", the third poem in a trio with "What bodes" and "For all", finds the poet-speaker at home, where his wife is both absent and present: "I find you/next to me/for all you/are not here/as yesterday/tomorrow/and today ${ }^{49}$ ". Taking this logic a step further, "So far" suggests that there is but a thin skin separating the (seemingly) living from the (supposedly) dead. The poem describes someone "throwing/pebbles at/an unanswered/window"; the person can see "shadows" moving behind this window, just out of reach, and s/he laments "how ... / difficult it is/for the living/to get through ${ }^{50 "}$. Finally, "To enter" actually sketches a kind of "portal" through space-time: here Belfast is framed as "ever bleeding/into that other/city glimmering/within this one $^{51}$ ". In other words, the universe defies our conceptions of fixed space and linear time, and Carson wonders if we might find a way to apprehend life as it "glimmers" beyond our perceptual limits.

\section{The backstitch}

Traditional Irish music is also central to Until Before After, both in terms of theme - Carson and his wife play tin whistle and fiddle together, and many scenes

\footnotetext{
46. Colin Graham, “'strange architecture’: Ciaran Carson's Until Before After”, Irish University Review 43.2, 2013, p. 396.

47. Ciaran Carson, "What is", op. cit., lines 1-5.

48. Ciaran Carson, "What bodes", op. cit., lines 1-3; "For all," lines 8, 10.

49. Ciaran Carson, "Asleep", op. cit., lines 1-7.

50. Ciaran Carson, "So far", op. cit., lines 2-14.

51. Ciaran Carson, "To enter", op. cit., lines 2, 7-10.
} 
of music-making appear in the book - and of form. Indeed, in his Acknowledgements, Carson explains that "[s]ome of the poems depend on the terminology of Irish traditional dance music, where the first part of a tune is often called 'the tune' and the second part 'the turn ${ }^{52 "}$; the volta that often appears in his modified fourteen-line "sonnets" is therefore more like the B-section of a traditional tune. This preoccupation with music, I suggest, is actually fundamentally connected to Carson's experiments in space-time, surprising though this confluence of a centuries-old art form and quantum physics might sound.

For one thing, Carson has described traditional tunes as being "capable of infinite variation ${ }^{53}$ ", indicating that (unlike Classical pieces) they are playerdependent and therefore open to endless reinvention. Additionally, as Carson indicates in his two full-length books on traditional music, The Pocket Guide to Traditional Irish Music (1986) and Last Night's Fun (1996), the genre can evade conventional measures of time. The tunes must be learned by ear, Carson says, because it is impossible to notate the flourishes that able players use to embellish the music. For instance, sometimes "a good musician can produce a pulse against the ostensible rhythm of the tune", a technique that Carson calls "double entendre - like hearing two beats at once ${ }^{54 "}$. Given these insights, I suggest that traditional music provides the basis for a new, non-Euclidean worldview in Until Before After: rife with its own double entendres, the poetry offers a kinetic, relativistic, non-linear means of apprehending space and time.

Carson's writing has long been indebted to the workings of traditional music ${ }^{55}$. In a 2009 interview with Elmer Kennedy-Andrews, Carson explained: "Some of my own work has been called 'genre-defying': maybe I learned that from the music, since every tune recalls other circumstances in which it has been played... The tunes themselves are ostensibly simple, but [...] [t]he music is always renewable in the light of the now ${ }^{56}$." Put otherwise, traditional music bears at once towards the past and towards the future - it "recalls" prior playings, but it is also infinitely variable - and Carson tries to capture this curious temporality in the poetry. Similarly, Last Night's Fun describes the ability of Cathal McConnell, a traditional flautist, to "slip" through a "vast cartography of time and place", bearing back "strange new tunes[,] [...] as if he were invisible", into today's

52. Ciaran Carson, op. cit., p. 109.

53. Ciaran Carson, "For All I Know: Ciaran Carson in Conversation with Elmer Kennedy-Andrews," op. cit., p.15.

54. Ciaran Carson, Last Night's Fun: In and Out of Time with Irish Music, New York, North Point Press, 1996, p. 11.

55. For details of the relationship of Carson's 'long line' poetry to traditional music, see Julia C. Obert, Postcolonial Overtures: The Politics of Sound in Contemporary Northern Irish Poetry, op. cit., chapter 3.

56. Ciaran Carson, "For All I Know: Ciaran Carson in Conversation with Elmer Kennedy-Andrews," op. cit., p. 15 . 
session $^{57}$. In other words, here, a player appears to time-travel on the back of a tune, simultaneously circling back to past playings and improvising his way into the future.

Until Before After is structured around this premise of "repetition with variation" - the notion that " $[\mathrm{t}]$ he musician [or the writer] does what he is doing [...] and then he does it again, only differently ${ }^{58 "}$ " As such, the volume ends where it began, "only differently": its final poem, "I open the door", echoes "open the door", the last line of "So it is", the second poem in the volume. However, where "So it is" opens a door to allow a soul to escape as "death draws/nigh59", "I open the door" does so with a new lease on life - here Carson and his wife return from the hospital, crossing their house's threshold and mounting the stair to their "room/full of light ${ }^{60 "}$. The gesture repeats itself, but it takes a different, more hopeful inflection the second time around; paradoxically, then, repetition admits newness into the collection.

Indeed, Carson clearly figures traditional music as a source of potentiality and novelty throughout the volume; the variability of the tune under different fingers (and likewise the poetic trope under successive renderings) provides for both wellworn patterns - a hearkening back to the song's long history - and the surprise of new possibility. As Carson elsewhere explains this seeming temporal paradox, "Each time the song is sung, our notions of it change, and we are changed by it. The words are old [...] But every time is new because the time is new, and there is no time like now ${ }^{61}$ ". The poem "From whom", for instance, dwells on an unnamed tune, one that goes so far back in his partnership with his wife that he cannot recall "whether/you [got it] from me/or I from you". This sense of collaboration, of a common musical language, is figured as central to their relationship in the volume, and this tune is a part of that intimately shared history. However, while the tune is familiar, it is far from frozen in time: the more often they play it together, Carson explains, the more they "happen/on other ways/around it". Indeed, though this song carries the weight of the past, Carson ultimately frames it as a bridge between present and future; the tune, he says, is "ever/changing into/what comes after ${ }^{62 "}$.

Likewise, "The turn", a direct address to (presumably) Deirdre, thematizes what might become of a favorite tune "in the light of the now ${ }^{63 "}$ : an improvi-

57. Ciaran Carson, Last Night's Fun, op. cit., p. 88.

58. Ciaran Carson, Pocket Guide to Irish Traditional Music, Belfast, Appletree Press, 1986, p. 7, 9.

59. Ciaran Carson, "So it is", op. cit., lines 2-3.

60. Ciaran Carson, "I open the door", op. cit., lines 13-14.

61. Ciaran Carson, Last Night's Fun, op. cit., p. 116.

62. Ciaran Carson, "From whom", op. cit., lines 2-4, 6-8, 9-10.

63. Ciaran Carson, "For All I Know: Ciaran Carson in Conversation with Elmer Kennedy-Andrews", op. cit., p. 15 . 
satory flourish - "turn[ing]/ a tune another/way" - can recast a seemingly familiar song in entirely new terms. As Carson puts it here, such "turnings" can "find what/one or other/never knew the tune/beyond the tune $e^{64 "}$. Moreover, with the word "beyond", the poem actually compresses past, present, and future into a single gesture; a tune with a rich history is re-envisioned in the present moment in a way that accesses something yet to come. This temporal compression is important to Carson, as it also reflects the poet's experience of his wife's illness. The first inkling of that illness ("The turn/you took abroad ${ }^{65 ")}$ is just as present to him in its traumatic power as is her current hospital stay ("this the aftertime/of what/has been ${ }^{66 ")}$, and his fantasies of the "beyond" also inhabit the present moment.

On this note, the poem's title points to the effects of ill-health ("the turn" Deirdre took abroad was perhaps the first symptom of her illness), but also, as I've suggested, to the B-section or latter half of a traditional tune. This understanding of "the turn" indicates the poet's desire for resolution, for his wife's healthy return home. However, given that tunes are played in cyclical, recursive ways during sessions - the same songs are repeated over and over with an eye (or an ear) to previous playings, but different players also offer their own variations on the tunes' themes - their endings are necessarily also beginnings. Indeed, a turn, if sharp enough, is also a return to one's point of departure. This poem therefore longs for finality (an end to an extended period of illness) even while acknowledging that finality as such is illusory. This acknowledgement admits the possibility of the illness's recurrence alongside its remission, but it also gestures towards the more radical possibility that even death itself is not absolute. As Carson explains in Last Night's Fun, traditional music teaches us that time is a loop rather than a line: the tune's "present time, imbued with yesterday, comes out with bent dimensions", and its capacity for infinite variability means that "[a]lternative universes loom before us with their many shadows" during each session ${ }^{67}$.

Beyond their relativism, traditional tunes also use figures that elude the calculus of mechanical time. As Last Night's Fun describes this phenomenon, sometimes ornaments "consist of the merest flick of the fingers, and seem to exist outside conventional time ${ }^{68}$ ". In Until Before After, for example, Carson discusses the "backstitch", a kind of staccato triplet that traditional players occasionally employ to embellish a tune - and, interestingly, an ornament that is virtually impossible to notate (and so must operate by the ear alone) because it confounds conventional time signatures. As the poem "It's one of those" describes this

64. Ciaran Carson, "The turn", op. cit., lines 9-11, 11-14.

65. Ibid., line 1.

66. Ibid., lines 5-7.

67. Ciaran Carson, Last Night's Fun, op. cit., p. 90, 189.

68. Ibid., p. 55. 
curious temporality, the backstitch forces the listener to "re-/negotiat[e] what/you thought/[the phrase] was", defying one's efforts to count one's way through the piece. Clock time "founder[s]" in the face of such ornaments, and the auditor is left "unstitched/by afterthought": the backstitch appears to fall after the beat, or between beats, in a way that bewilders the ear and that cannot be captured on the page $^{69}$.

The poem itself works similarly; its form is puzzling, with its line breaks often falling against the grain of its syntax. For example, when read alone, its third couplet, "negotiating what/you thought ${ }^{70 "}$, seems to refer to a one-time action in the present moment ("negotiating"). However, when the reader jumps back across the gap between the second and third couplets to recall the "re-" of line 4, she is reminded that the poem's temporality is actually recursive. Rather than "negotiating", we are "re-/negotiating", suggesting that we are revisiting a past action, that we have somehow been here before. In a sense, then, Carson's audience is "unstitched/by afterthought" when approaching this poem; its arrangement is "dodgy $y^{71}$ ", forcing the reader to loop back again and again through foregoing lines in search of a satisfying close reading (which it never quite delivers). Carson's form therefore matches his theme: time, the poem insists, is not neatly linear. This relativistic worldview, Carson reveals elsewhere, is rooted in his experiences of traditional music:

Some grooves are worn deeper in our brains than others, as we go back to a favourite tune at staggered intervals; or, mental synapses are zapped, creating fractal pathways where we scarcely know the route, as when we hear a tune we used to play, played differently by someone else. Perhaps the person picked it up from us directly, many years ago; maybe it had gone through many hands, as it must have done before it reached our ears; and who knows where it starts or ends ${ }^{72}$ ?

These "fractal pathways" fundamentally shape Until Before After. Linguistic patterns recur throughout the collection, with later turns of phrase sending the reader back through earlier poems in search of their syntactical counterparts (particularly since each telegraphic poem, taken alone, is quite difficult to parse). Although the collection does follow a kind of chronology, moving through Carson's wife's illness, it also builds in its own wormholes, developing synaptic connections between distant poems that confound linear readings. As I've suggested, this strategy has a therapeutic value in the volume: by making the point

\footnotetext{
69. Ciaran Carson, "It's one of those," op. cit., lines 4-7, 11, 13-14.

70. Ibid., lines 5-6.

71. Ciaran Carson, Interview with John Brown, op. cit., p. 151.

72. Ciaran Carson, Last Night's Fun, op. cit., p. 110.
} 
that seeming absolutes - including concepts of past, present, and future - are actually subjective, Carson contests death's finality. As he contemplates his wife's mortality, imagining thresholds or "portal[s]" between dimensions and envisioning the city that "shadow[s]", the one that he himself appears to inhabit allows Carson to deconstruct the concept of the "afterlife " $^{73}$ ". If time is observerdependent, then "after" is a relative term; could one occupy a different perspective, perhaps by experimenting with velocity or the effects of gravitational pull, one might see "that other/[ghostly] city glimmering/within this one ${ }^{74}$ ". Again, given that Carson has explicitly expressed an interest in quantum physics, and a conviction that "the essences of things can cross space and time", it is perhaps unsurprising that his poetry has come to bear out these "crossings $s^{75}$ ". In light of these observations, we might rethink the volume's title: rather than reading punctuation into Until Before After and treating each term (and each temporal unit) independently ("Until, Before, After"), we should take the title as given. Without implied commas, the phrase "Until Before After" collapses notions of chronology, describing instead a state of perpetual simultaneity. This volume orients itself towards such simultaneity, and Carson uses the concept, as Einstein did before him, to reimagine the dead among the living.

73. Ciaran Carson, "To enter", op. cit., line 2; "Of assignations", op. cit., line 8. Additionally, perhaps this statement accounts for Carson's interest in China Miéville (whom he recognizes in the collection's Acknowledgements) and Haruki Murakami's work. Carson has explained, for instance, that he loves Murakami's HardBoiled Wonderland and the End of the World for its engagement with an "Otherworld", and its depictions of characters moving "in and out of that world through dream portals" (interview with John Brown, op. cit., p.148). A similar kind of movement is apparent in Until Before After.

74. Ciaran Carson, "To enter", op. cit., lines 8-10.

75. Ciaran Carson, Interview with John Brown, op. cit., p. 151. 